\title{
Evaluation of Communication Skills with Audio-Visual Aids
}

\author{
Anna Barnau, Božena Džuganová \\ Jessenius Faculty of Medicine, Comenius University (Slovakia)
}

\begin{abstract}
English, a global language, is the most popular communication tool which is used as a lingua franca. For nursing students it is necessary to have a very wide range of stimulating activities developing communicative competence and performance. This study presents an investigation into the effects of implementation of audiovisual material into the teaching and learning process as well as its impact on communication evaluation and testing in intermediate learners of English at Jessenius Faculty of Medicine in Martin, Comenius University in Bratislava, Slovakia (JFM CU). Two groups of twenty first-year students participated in the same teaching unit and fulfilled the same communicative tasks. Group one (G1), however, learned without the help of audiovisuals, whereas group two (G2) used audio-visual aids. After two weeks, students took a communicative language test in order to assess their linguistic and communicative competences. The results of the communicative test supported our hypothesis that audio-visual materials enhance English learning.
\end{abstract}

Keywords: Audio-visual aids, communication skills, evaluation, English for nurses, t-test

\section{Introduction}

\subsection{Communicative Language Teaching}

The central theoretical concept in communicative language teaching is "communicative competence," a term introduced into discussions of language use and second or foreign language learning in the early 1970s [1, 2, 3]. Thus, the emphasis is no longer on linguistic accuracy, vocabulary and grammar, but on the ability to function effectively through communication and discussion in the target language in particular contexts of situation [4]. One of communication teaching methods is the usage of visual aids. Places, objects and people are presented through pictures and the students have to learn to work with them. Andrew Wright in his monograph Pictures for Language Learning stresses that visual material contributes to interest and motivation; a sense of the context of the language; and a specific reference point or stimulus [5].

However, it is necessary to stress that visuals should be subjected to some criteria for assessment of their value. The problem concerning the usage of audio-visual aids as a source of information is connected with student's visual literacy. It means that students are not always critical to visual information, nor understand how to interpret it. Being critical in interpreting pictures as a source of information allows one to analyze as well as synthesize images and information [6]. Thus, teaching all four skills needs to include visual aids in innumerable ways. Pictures no longer exist to entertain or illustrate, but they communicate in the way that we have to see, understand and use them. Only when an individual is conscious of the message, intent and the meaning of visuals, is he or she visually literate. Without knowledge of how pictures function in the visual communication process a human being becomes a subject of a one-way communication, a communication without any possibility to respond $[7,8]$. 


\subsection{Communicative Language Assessment}

The central theoretical concept in communicative language teaching is communicative competence and performance. Canale and Swain chose the term 'communicative competence' to refer to the knowledge of the rules of grammar, and sociolinguistic competence, or knowledge of the rules of language use [9]. According to the scholars' definition, an individual cannot directly measure competence because only performance is observable. Put in another way, communicative testing cannot be only focused on what the student knows about the second language and about how to use it (competence) but also on to what extent the student is able to demonstrate this knowledge in a meaningful communicative situation (performance) [9]. Consequently, paper tests, which are very popular nowadays, do not necessarily give valid information about the student's communication skills in a real situation. Thus, it is necessary to understand the model of communicative competence in order to develop communicative language tests, which involves formulating test objectives and dealing with the effects of the test on teaching and learning processes [10].

Because communication takes place in many different contexts, it is necessary to evaluate not only student's the language knowledge, but consider cognitive, cultural and social goals of evaluation, too. Consequently, it is important to pay closer attention to the particular tasks, purposes and settings [11]. Thus, assessment is not limited to tests only, but includes a variety of language activities that students are involved in during the English language course.

The most used activities improving students' oral language performance that requires a description/discussion from the test participants are picture-cued tasks, responsive speaking, interactive speaking (interview), and extensive speaking (presentation) [12].

\subsection{Research Questions and Hypotheses}

Audio-visual aids motivate students to learn the foreign language; they stimulate and provoke them to speak. Visuals provide an authentic situation in which language is used; they reduce anxiety about making mistakes during communication in foreign language [11]. This is the reason to study the process and effectiveness of using audio-visual materials to improve English language students' communicative skills as well as an opportunity to test and evaluate the results. The following questions have been addressed in the present research study.

1. Do the audio-visual materials help achieve higher scores in the communicative test and enhance English language learning?

2. Do the students prefer to fulfill the tasks with or without audiovisuals?

As hypotheses it was assumed that

3. The audio-visual materials help achieve higher scores in the communicative test and enhance English language learning.

4. The students prefer to fulfill the tasks with audiovisuals.

\section{Methodology}

\subsection{The Sample and Setting}

Twenty English language nursing students from JFM CU participated in the present study. They were firstyear nursing students learning English who had passed the final leaving exam in English targeted at Level B2 of the Common European Framework of Reference for Languages (CEFR) [13]. All students participated in the research study during their regular class. The participants were divided into two groups, $\mathrm{N} 1$ was the sample size of group one and $\mathrm{N} 2$ was the sample size of group two $(\mathrm{N} 1=10, \mathrm{~N} 2=10)$. 


\subsection{Communicative Language Assessment}

All test participants had to accomplish the same tasks in a communicative language test which followed two weeks after the teaching unit. The following tasks were assessed.

1. A picture-cued task with the composition of a series of pictures providing information relevant to the procedure for drawing blood.

2. An interactive speaking task that involved the presentation of the dialogue between a patient and a nurse taking a blood sample.

3. A responsive speaking task included questions and answers concerning the blood clotting process.

Grammar, vocabulary, comprehension, fluency, and pronunciation were categories used by the test administrator for scoring of the three communicative tasks (total score of 36 points). Each category was evaluated and scored separately. The following table presents the categories of oral proficiency scores in testing English for Nurses.

TABLE I: Categories of Oral Proficiency Scores in Testing English for Nurses

\begin{tabular}{|c|l|}
\hline $\begin{array}{c}\text { Grade } \\
\text { percentage })\end{array}$ & \multicolumn{1}{c|}{ Description } \\
\hline $\begin{array}{c}\text { Fx } \\
(<59)\end{array}$ & Unable to function in the spoken language. Errors in grammar are frequent and speaker cannot be understood. \\
\hline $\begin{array}{c}\text { E } \\
(60-65)\end{array}$ & $\begin{array}{l}\text { Able to satisfy minimum requirements and maintain very simple face-to-face conversations on simple nursing } \\
\text { topics. Errors in grammar and pronunciation are frequent, but speaker can be understood. }\end{array}$ \\
\hline $\begin{array}{c}\text { D } \\
(65-72)\end{array}$ & $\begin{array}{l}\text { Has speaking vocabulary sufficient to express him/herself simply with language usage that is often, but not always, } \\
\text { acceptable and effective. Can deal with elementary constructions accurately but does not have control of the } \\
\text { grammar. }\end{array}$ \\
\hline $\begin{array}{c}\text { C } \\
(73-80)\end{array}$ & $\begin{array}{l}\text { Can speak the language with sufficient structural accuracy and vocabulary to participate effectively in most } \\
\text { conversations on nursing topics. Vocabulary is broad enough that he/she rarely has to search for a word or an idea. } \\
\text { Errors in pronunciation rarely disturb understanding. }\end{array}$ \\
\hline $\begin{array}{c}\text { B } \\
(81-90)\end{array}$ & $\begin{array}{l}\text { Able to use the language fluently and accurately. Can understand and participate in a conversation with a high } \\
\text { degree of precision of vocabulary. Errors in pronunciation are rare. }\end{array}$ \\
\hline $\begin{array}{c}\text { A } \\
(91-100)\end{array}$ & $\begin{array}{l}\text { Grammar, vocabulary and speaking proficiency are functionally equivalent to that of native speaker and reflect the } \\
\text { cultural standards of the country where the language is spoken. }\end{array}$ \\
\hline
\end{tabular}

\section{Procedure}

Our present study took place in two classrooms at JFM CU in Martin, Slovakia. Whereas the lesson of G1 was taught and evaluated without audio-visual material, however, G2 used pictures and audiovisuals. For the present study we chose the topic "Blood" that was part of our teaching curriculum. Two weeks after the teaching unit the students took the communicative language test. The test administrator considered the following categories for scoring of the tasks: grammar (2 points), vocabulary ( 2 points), comprehension ( 2 points), fluency ( 2 points), pronunciation ( 2 points), and task fulfilment ( 2 points). The results in both groups of test participants were then compared and statistically evaluated.

\subsection{Picture-Cued Task}

The picture-cued task was aimed at the elicitation of oral production through pictures. The visuals were used as a stimulus for a longer description of the procedure of drawing blood. First, the students were asked to put pictures in the correct order and then, according to these pictures, they had to describe the procedure of drawing blood. The objectives of eliciting narrative discourse were production of a correct sentence or phrase.

\subsection{Interactive Speaking}

The students' assignment was to prepare a dialogue between a patient and a nurse taking a blood sample. At first, the exercise was practiced in the form of a pair work activity in class. Later, interactive speaking was chosen as the most common oral production task for assessment. A test-taker and a test administrator proceeded 
through a set of questions and directives. As well as linguistic and literacy competence, task comprehension, accuracy in pronunciation and fluency, the parameters of sociolinguistic appropriateness and task accomplishment were also tested [4]. The interview lasted from five to ten minutes, depending on the linguistic competence as well as communication skills of the test-takers.

\subsection{Responsive Speaking}

The task was based on a previous video watching activity practiced during the English lesson. The video "How Does Blood Clot?" was taken from YouTube. While G1 students only listened to the spoken text, G2 learners watched the video with captions. All questions, prepared by the teacher, combined testing of grammatical and discourse competence.

After the teaching unit as well as at the end of the communicative test, 20 students answered the question in the questionnaire [14].

\section{Results and Discussion}

\subsection{Two Sample T-Test with Unequal Variances}

In our hypotheses, we presupposed that audiovisuals would enhance English language learning as well as help achieve higher scores in the communicative language test. Statistical analyses were based on a comparison of G1 and G2 learning English with/without audio-visual materials. For data analyses we used two sample t-test with unequal variances. There was a statistically significant difference in the picture-cued task $(p=0.0097)$, in the interactive speaking task $(p=0.0068)$, and in the responsive speaking task $(p=0.023)$. Quantitative results are presented in Table 2 showing the number of participants as well as their mean scores, standard deviation (SD) and standard error of the mean (SEM).

TABLE II: Quantitative Results of the Tests

\begin{tabular}{|c|c|c|}
\hline Task & \multicolumn{2}{|c|}{ Communicative test Forms } \\
\hline 1. Picture-cued & G1 (no audiovisuals) & G2 (audiovisuals) \\
\hline Mean & 6.20 & 8.90 \\
SD & 2.49 & 0.50 \\
SEM & 0.79 & 10 \\
N & 10 & G2 (audiovisuals) \\
\hline 2. Interactive speaking & G1 (no audiovisuals) & 8.70 \\
Mean & 6.10 & 2.41 \\
SD & 1.20 & 0.76 \\
SEM & 0.38 & G2 (audiovisuals) \\
N & G1 (no audiovisuals) & 10.90 \\
3. Responsive speaking & 8.70 & 1.45 \\
SD & 2.41 & 0.46 \\
SEM & 0.76 & 10 \\
\hline
\end{tabular}

\subsection{Questionnaire}

At the end of the teaching unit "Blood" as well as the communicative language test, the students were asked to respond to an open question "Did you prefer to fulfill the tasks with audio-visual aids?" The five point Likert scale was used to evaluate the responses: $1=$ Strongly disagree, $2=$ Disagree, $3=$ No opinion, $4=$ Agree, $5=$ Strongly agree. Since all students participated in classroom activities containing audio-visual material during the semester, it was possible for them to make the comparison. The answers to the open question revealed that $90 \%$ of students preferred the activities and tasks with audio-visual materials, reflected by an average rating of 4.51 points on the Likert scale. 


\section{Conclusion}

Language competences and communication enable people to study and work not only in European states, but all over the world with English arguably the most popular global communication tool. Communicative language teaching and testing activities contribute to better development of communicative competence and performance in nursing students and prepare them for their future professional life, which begins with a job interview and continues during their career as nurses in real communication with patients. In this connection, communicative language tests require test participants to show their ability to combine language skills as in real life situations.

Our study confirmed that audiovisuals contribute to better communication performance of test-takers, which was measured by awarding points according to the Categories of oral proficiency scores in testing English for Nurses and led to better scores in G2 students.

As open-ended tasks include some unreliability, there is a problem when using the A to Fx range for scoring. Special attention was thus paid to linguistic as well as communicative criteria. It is necessary to say that teachers should prepare such types of tests to measure students' real language competence and performance to make tests more reliable.

\section{References}

[1] J. Habermas, Toward a Rational Society: Student Protest, Science, and Politics, Beacon Press, 1971.

[2] D.H. Hymes, "On Communicative Competence" in Sociolinguistics: Selected Readings, Ed. J.B. Pride and J. Holmes, Harmondsworth: Penguin, 1972, pp. 269-293.

[3] S. J. Savignon, "A Study of the Effect of Training in Communicative Skills as Part of a Beginning College French Course on Student Attitude and Achievement in Linguistic and Communicative Competence," Doctoral dissertation, University of Illinois: Urbana-Champaign, 1971.

[4] C. J. Weir, 1980-2010 Testing Communicative Language Use: A Brief Overview. [Online]. Available: http://www.beds.ac.uk/_data/assets/pdf_file/0011/83855/Weir_LTF2010.pdf

[5] A. Wright, Pictures for Language Learning, Cambridge: Cambridge University Press, 2006.

[6] K. S. Fleckenstein, "Teaching Vision: The importance of Imagery in Reading and Writing," in Language and Image in the Reading-Writing Classroom: Teaching Vision, Ed. K. Fleckenstein, I. Calendrillo \& D. Worley, Mahwah, NJ: Erlbaum, 2002.

[7] A. C. Saunders, "Graphics and How They Communicate," in Visual Literacy: A Spectrum of Visual Learning, Englewood Cliffs, NJ: Educational Technology Publications, Inc., 1994, pp. 183-192.

[8] P. Felten, "Resource Review: Visual Literacy," in Change: The Magazine of Higher Learning, 40 (6), 2008, pp. 60-64. Available: http://www.changemag.org/Archives/Back\%20Issues/November-December\%202008/abstract-visualliteracy.html

[9] M. Canale, M. Swain, "Theoretical Bases of Communicative Approaches to Second Language Teaching and Testing," in Applied Linguistics, pp. 1-47, January 1980.

https://doi.org/10.1093/applin/I.1.1

[10] A. Barnau, "Effective communication and visual aids in teaching ESP - a process and outcome evaluation," in Proc. Trendy v jazykovém vzdělávání v terciárni sfére v jazykových centrech na FF v ČR a SR 2 : testováni a méření jazykových kompetencí, 2015. Available: https://www.kal.upol.cz/fileadmin/kal/dokumenty/veda-vyzkum/trendy-vjazykovem-vzdelavani-ii/BARNAU_EDIT_FINAL.pdf

[11] A. Barnau, "Vizuálna podpora ako motivačný faktor vo výučbe angličtiny u študentov ošetrovatel’stva" (Visual Support as a Motivating factor of Teaching English in Nursing Students) in Cizí jazyky. (2014/2015), vol. 58, issue 5 pp. 25-37.

[12] B. Džuganová, "Presentations of Specialized Topics as a Way of Testing Communication Skills," in Testing language competence of tertiary students in LSP courses: collective monograph, Hradec Králové, 2014, TAH reklamní agentura, pp. 8-15. 
[13] Common European Framework of Reference for Languages: Learning, Teaching, Assessment. $\quad$ Language Policy Unit, Strasbourg. Available:

https://www.coe.int/t/dg4/linguistic/Source/Framework_EN.pdf

[14] Z. Dornyei, Questionnaires in Second Language Research. Construction, Administration and Processing, London: Lawrence Erlbaum Associates, 2003. 